\title{
THE PART PLAYED BY THE SUBSOIL OR GROUND WATERS IN THE CAUSATION OF TYPHOID FEVER.*
}

By EDGAR D. WELLBURN, L.R.C.P. AND S. (ED.), F.G.S., Medical Officer of Health for Sowerby Bridge, etc.

\section{Season.}

IN the Northern temperate zone typhoid fever appears to be most prevalent during the last six months of the year-from July to December-being most severe and widespread in September, October, and November. Murchison cites 27.7 per cent. as occurring during October and November, but only 7.3 in April and May.

During the years 1894 to 1898 the writer found that in the West Riding of Yorkshire the maximum curve occurred in October in the years 1894, 1895, and 1898; in 1897 the maximum curve was during September and October, the top of the curve being nearly level; whilst during 1896 the highest point was in August, with a very slight fall during September, and then another slight rise in October. The minimum curve in the above years was during May and June.

\section{RainfaliL.}

During the five years 1894 to 1898 the writer found that there was a very distinct relation between the rainfall of any given year and the height of the fever curve for that year, the curve being most marked and the apex of the curve the highest during that year where there was the greatest rainfall; but it is probable that the effect of the rainfall in the causation of typhoid fever is really indirect, and is due rather to its effect in causing a liberation of the gases of noxious matters-containing the specific microbe-in the drains, sewers, and the subsoils, and I hope to show later that the subsoils do play an important part in the production of this disease under certain conditions.

Dr. MeWeeneyt has demonstrated that a heavy rainfall will carry $B$. prodigiosus through a considerable depth of subsoil into the water-mains; and this being so, it seems to be reasonable to suppose that $B$. typhosus may also in like manner be carried through the subsoils into the water-supply.

\footnotetext{
* Extract from a paper read at the meeting of the Yorkshire Branch of the Incorporated Society of Medical Officers of Health, on February 7th, 1902.

+ Journ. of State Med., January, 1900, pp. 47-50.
} 


\section{Subsoll or Ground Waters and Subsolls.}

In the opinion of the writer, ground water will under certain conditions have an important bearing on the causation of this fever. For instance, should the water lie at a point near the surface, and should it be liable to become stagnant there, owing to the geological nature of the subsoils, and given an infection of the water-from some leaking cesspool or other source-with the specific bacillus, then it seems to be highly probable, if not certain, that it will be a factor of very great importance; and, again, at greater depths its influence is well worthy of our consideration, but whether the disease is due to a high* or a low level of the ground water most authors appear to be in doubt; to many a fluctuation is considered to be of the most importance. To the writer it appears to be very likely that all these conditions may, under certain circumstances, play an important part in the causation of typhoid fever; but before discussing this question it seems to be advisable to study a few geological facts which have an important bearing on the question of the depth at which the ground water may lie below the surface in any given district. This point appears to the writer to be the all-important one for consideration, as in some districts the ground water cannot have any influence in the causation of this disease, owing to the geological peculiarities of the subsoils. Geological knowledge is of the greatest use, as by its means the intelligent geologist will have a fairly correct knowledge of the nature of the rocks which lie below the surface, their constitution, and their inclination or dip-points which are of the highest importance. Where the dip is pronounced the subsoil waters will be carried away to lower and deeper levels; and should there be no wells, etc., used for water-supply on such lower levels, the danger of an epidemic will, in all likelihood, be nil; but, on the contrary, should wells be present, and should their water be used for domestie purposes, then, given the specific pollation, the danger will be very great. I hope to show that polluted ground waters are only a causus operandi in the causation of this disease under certain conditions, viz., when they lie at a point relatively near the surface, and especially when they are liable to become stagnant there owing to the nature and inclination of the subsoil, rocks, or where, owing to the dip of the strata, the polluted waters are carried to any well, springs or watercourses at a lower level; and, considering these facts, it is of vital importance to settle the question of the depth from the surface of the first impervious or water-bearing rocks, and also their dip or inclination in any district under investigation. 
In a previous paper* I have tried to show that this will vary greatly in different districts. In some the rocks may be porous to a considerable depth, whilst in others the first impervious stratum may be at, or very near, the surface; but the intelligent geologist, and especially he who studies the surface or contour geology of a district-aided by exposures of the rocks in quarries, railway cuttings, cut-out roadsides, ete.-will in most cases have a pretty correct knowledge of the nature and inclination of the subsoils in most districts. But it must be borne in mind that his calculations, however carefully made, may be upset by faults, contortion, etc., whereby the depth and inclination of the rocks may be so altered as to have an entirely different dip in another part of the same district, and in some instances, where the rocks show an inclinacion at the surface, at greater depths their direction may be entirely altered, and even pockets of impervious rock may be formed, with the result that the subsoil water would here become stagnant, and should such water become polluted with the typhoid germs, and a well be sunk on such a site, the result would be very serious. In most cases, however, there would be certain indications of these latter conditions-hence the great advantage of a geological training to the sanitarian who seeks to determine the effect of the subsoil waters in the causation of typhoid fever. From the above remarks it will be seen-as already pointed out-that, in trying to trace a connection between the subsoil waters of any given district and the occurrence of typhoid fever there, it will be essential to take into consideration the geological peculiarities of that district, whereby the depth and direction of flow of the subsoil waters will be determined.

Porosity of the subsoil rock-which will depend on their petrological characters-greatly influences the quantity and flow of the ground water, so that the nature of the subsoil should not be lost sight of in considering this question; and it may be stated that the following rocks are permeable, viz., chalk, sand, sandstone, vegetable soils, etc, whereas unweathered granite, trap, metamorphic rock, clay slate, dense clays, hard oolite, hard limestone, and dolomite are impervious. It may also be mentioned that roots of trees greatly retard the flow of ground waters.

After the above, we may now proceed to consider the conditions under which the subsoil waters are likely to play a part in the causation of this disease, and I propose considering the question according to the depth of the subsoil or ground water from the surface.

* "Geology : its Practical Application in Sanitation " (Journ. of State Med., 1899, pp. 1.8.) 
I. Subsoil or Ground Water near the Surface.-In some districts the first impervious or water-bearing rock may lie at a point very near the surface; or, again, on the hillsides of the same or another locality the water may - owing to the inclination of the rock -be carried to a point at or close to the surface; and this being so, it seems to be best to consider the two points separately.

(a) Ground Water very near the Surface.-That this is often the case there can be no doubt, as on many hillsides (especially after heavy rains) the water may be seen flowing out of the ground close to, around, and even under, the basements of the houses; and this being so, it seems to be reasonable to suppose that the water would only need a pollution with the typhoid poison from some leaking cesspool or other source at a higher level on the dip slope to produce a serious state of things. Any watercourses present might also become polluted, with serious results, and this would probably be the case whether the ground waters were low, fluctuating, or high, the two latter conditions being in all likelihood the more serious.

(b) Ground Water near the Surface (less than 6 feet deep).- - Here the polluted water, if low, would most likely act on wells and springs, if any existed, at a lower level; or in some instances it is reasonable to suppose that the water-supply might become infected through the mains. Under the above conditions a fluctuating ground water would be most likely to act on the wells, springs, or watier-supply if, although fluctuating, it were relatively low, wheress were it high it would in all likelihood disturb any typhoid-germ-laden ground air and drive it into the higher layers of the subsoils, and thus it might be sucked through the ground for many feet into any habitations on such a site; or, again, it might infect the water-supply; or were the ground water very high, the poisoned ground air might be even driven into the external air.

2. Subsoil Waters at some Distance from the Surface (about 12 feet).*-At these greater depths the subsoil water would probably have no action on any bacteria in the subsoils above, as the deeper we descend the less is the nutrient material left in the soil, which, so far as organisms are concerned, is found to be practically sterile at the depth of about 12 feet, varying, however, with the nature of the soil. Cultivated soil possesses more organic matter than similar uncultivated ground, is therefore more suitable for bacterial life, and under these conditions bacteria will probably extend

* These depths are simply given for sake of argument, and have no special significance. 
to greater depths; but it is likely that under the most favourable conditions they do not extend further than a very few feet below the surface. Considering the fact that B. typhosus is aërobic, and so will not live at any great depth in the subsoil, it seems to be probable, if not certain, that the ground water, so far as its position is concerned-whether high, low, or fluctuating-would have, under the above conditions, no effect on any bacteria in the subsoils above; but on the other hand, should it become polluted with the typhoid poison, then, of course, wells or springs on the same or a lower level are likely to become poisoned.

3. Subsoil Waters at a Considerable Depth. - Here the ground water, if polluted, would probably only have an effect (whether low, fluctuating, or high) on any deep wells situated at a lower level on the dip slope than the polluting area, whereas at still greater depths the subsoil waters would in all likelihood have little or no effect in the causation of typhoid fever; and, again, in some districts the water, if polluted, would be, owing to the geological peculiarities of the subsoils, rapidly carried away to deeper levels, and so away from danger.

Staphylococcio Enteritis in Breast-fed Infants.-Moro (Jahrbuch fiür Kinderheilkunde, 1900, Band ii., S. 530) has undertaken to investigate the causation of an enteritis in breast-fed babies which cannot be explained by the ordinary causes due to dietetic errors in the mother, or by such accidental disturbances as overfeeding or simple exposure to cold. He has examined in Escherich's clinic the stools of nurslings affected with dyspeptic troubles, and in a large number of these cases has found staphylococci.

This staphylococcic enteritis begins as an acute intestinal catarrh. Vomiting and loss of weight do not occur, and fever is rare. The stools, which are acid in reaction, are ordinarily serous, and are expelled in a jet. Recovery is the rule.

If the stools are examined by the staining method of WeigertEscherich, it is observed that the "blue" coli bacilli which normally exist in the stools of breast-fed infants are almost entirely replaced by staphylococci. Few at the beginning of the enteritis, they increase during the progress of the trouble, and disappear as the infant recovers, when they are replaced by the blue coli bacillus. These organisms, whether white or golden, are not virulent for mice or rabbits. They manifestly come from the mother's milk, being derived from the skin or from the superficial parts of the galactophorous canals, and are swallowed with the milk. The reason why all breast-fed infants are not thus affected depends upon the number of organisms entering the milk, upon the resistance of the organism of the infant, and upon the bactericidal power of its digestive juices.-Amer. Jour. Med. Sc. 